\title{
Studies on production potential of cape gooseberry (Physalis peruviana L.) in sodic soil under varying agronomic manipulations
}

\author{
Angrej Ali ${ }^{*}$ and B. P. Singh ${ }^{2}$ \\ ${ }^{\mathbf{1}}$ Faculty of Agriculture, Sher-e-Kashmir University of Agricultural Sciences and Technology of Kashmir, Wadura \\ Campus, Sopore-193 201 (Jammu \& Kashmir), INDIA \\ ${ }^{2}$ Department of Horticulture, Narendra Deva University of Agriculture and Technology, Kumarganj, Faizabad-224 \\ 229 (Uttar Pradesh), INDIA \\ *Corresponding author. E mail: anghort@gmail.com
}

Received: July 9, 2015; Revised received: October 30,2015; Accepted: March 8, 2016

\begin{abstract}
Present study aimed to evaluate the production potential of cape gooseberry (Physalis peruviana L.) in sodic soil $(\mathrm{pH} 8.56)$ under varying plant spacing and soil fertility levels. The spacing treatments were $S_{1}-75 \times 60 \mathrm{~cm}$, $S_{2}-75 \times 75 \mathrm{~cm}$ and $S_{3}-90 \times 75 \mathrm{~cm}$, while native soil fertility was manipulated through the application of NPK fertilizers i.e. $F_{0}$-control (no NPK fertilizers), $F_{1}-60: 40: 40, F_{2}-80: 60: 60$, and $F_{3}-100: 80: 80 \mathrm{~kg} \mathrm{NPK}$ ha $^{-1}$. Two year's data from the study revealed that spacing and NPK treatment had significant effect on vegetative growth and fruit yield during both the years. Closest spacing $(75 \times 60 \mathrm{~cm})$ resulted tallest plants $(103.41$ and $100.35 \mathrm{~cm})$ and maximum fruit yield $\left(86.69\right.$ and $\left.83.56 \mathrm{q} \mathrm{ha}^{-1}\right)$, but this treatment was statistically at par with $75 \times 75 \mathrm{~cm}$ spacing. Widest spacing $(90 \times$ $75 \mathrm{~cm}$ ) resulted maximum number of branches (34.14 and 32.49 plant $\left.^{-1}\right)$, number of leaves (167.31 and162.70 plant ${ }^{-1}$ ) and average fruit weight $(9.26$ and $9.18 \mathrm{~g})$, but was statistically at par with $75 \times 75 \mathrm{~cm}$ spacing. Amongst the fertilizer treatments, application of NPK @100:80:80 kg ha ${ }^{-1}$ resulted maximum plant height $(114.88$ and $11.65 \mathrm{~cm})$, number of branches (35.78 and 34.82 plant $\left.^{-1}\right)$, number of leaves (174.82 and 172.55 plant $\left.^{-1}\right)$, fruit weight $(9.62$ and $9.57 \mathrm{~g})$ and fruit yield (101.08 and $98.08 \mathrm{q} \mathrm{ha}^{-1}$ ). Biochemical quality of fruits (TSS, ascorbic acid, acidity, and reducing, non-reducing and total sugars) was increased due to increased fertility level and recorded maximum with the application of 100:80:80 kg NPK ha ${ }^{-1}$. These findings will be helpful in exploring cape gooseberry cultivation in sodic soils $(\mathrm{pH} 8.56)$ through suitable agronomic manipulations in plant spacing and soil fertility levels.
\end{abstract}

Keywords: Cape gooseberry, Physalis peruviana, Productivity, Soil fertility, Spacing, Vegetative growth

\section{INTRODUCTION}

The genus Physalis of the family Solanaceae consists of quick growing short duration herbaceous annual as well as short perennials shrub; originating from North and South America, Asia and Europe (Crawford, 2004). Several species of Physalis have edible fruit. A species which bears superior quality fruits and has become widely known as cape gooseberry (Physalis peruviana L.) that has been spread by explorers and travelers worldwide, but it is still considered a backyard fruit in most areas. It is native to Peru and Chile (Legge, 1974); although the name 'Cape gooseberry' was derived from the 'Cape of Good Hope' of South Africa (Klinac, 1986). The crop is reportedly cultivated in South Africa, Kenya, India, Egypt, New Zealand, the Caribbean, South East Asia, California, Columbia and Hawaii (Klinac, 1986; Chattopadhyay, 1996). The attractive golden colour berry (fruit) of cape gooseberry are eaten fresh and used for preparation of excellent quality of jam for which it is also called the 'Jam Fruit of India' (Majumdar, 1979). Edible portion of berry contains $11.5 \%$ carbohydrates, $1.8 \%$ protein, $0.2 \%$ fat,
$3.2 \%$ fibre, $0.6 \%$ mineral matter and $49 \mathrm{mg}$ ascorbic acid per $100 \mathrm{~g}$ edible portion of fruit (Khan and Gowder, 1955). The fruits are one of the potential sources of vitamin A (2380 I.U.) (CSIR, 1969) and pectin 0.9\% (Majumdar and Bose, 1979).

In recent past, the cape gooseberry is gaining importance in several countries including India (Trinchero et al., 1999; Fischer et al., 2011). The economical potential of cape gooseberry as fruit crop is being realized due to its quick growing in nature, high productivity, non-perennial occupation of land (Prasad et al., 1985). Because of wide adoptability to varying soil conditions without much care (Morton, 1987); the cape gooseberry finds itself more acceptable in marginal lands either as monocrop or in mixed cropping with other fruit trees. The available normal soils while however under the cultivation of major crops in most of the regions, some minor crops such as cape gooseberry has vital for their cultivation in marginal lands in view of horizontal increase in fruit production, also their inclusion in crop diversification for sustainable agriculture.

Apart from genetic potential of the crop, the growing environment (viz. soil conditions, cultural practices) 
have profound effects plant growth and yield. Soil salinity as one of the biggest problems affects about one-third of irrigated land in the world (Mengel et al., 2001). Its extent throughout the world is increasing regularly (Schwabe et al., 2006), which has now become a very serious problem for crop production with adverse effects on germination, plant vigour and crop yield (Munns and Tester, 2008). In the Indian context, salt affected soils occupy about 6.73 million ha area (Sharma and Gupta, 2010). Selection of suitable crops is one of the considerations for successful crop cultivation under soil salinity conditions. According to Morton (1987) cape gooseberry is fairly adaptable to a wide variety of soil conditions. According to Miranda et al., (2010), cape gooseberry is often grown in salt affected soils in Columbia. While so far solanacious vegetables concern, those are close affinitive to cape gooseberry, these crops respond well to applied fertilizers in terms of yield and quality. Further, plant spacing or plant population per unit area may have decisive role with regards to optimum growth of plant and fruit yield. Ayala (1992) indicated that the planting scheme of Physalis ixocarpa is of the greatest significance for high yield. According to Mortom (1987) cape gooseberry is said to succeed wherever tomatoes grown. However, while for other close affinities of cape gooseberry (e.g. tomatoes and egg plant, capsicum), a lot of information and practical recommendations are exit, but the literature sources for cape gooseberry are very scant. Growing consumer demand for this unique fruit, it is spurring a need for increased information on cultural techniques for cape gooseberry; more particularly in problem soils. This work aims to investigate the production potential of cape gooseberry in sodic soils of Eastern Uttar Pradesh (India) under varying levels of plant spacing and soil fertility levels.

\section{MATERIALS AND METHODS}

Site characteristics: The study was conducted at main experimental station of the Department of Horticulture, Narendra Deva University of Agriculture and Technology, Kumarganj, Faizabad (latitude $26^{\circ} 47^{\prime} \mathrm{N}$, longitude $85^{\circ}$ $12^{\prime}$ E, $113 \mathrm{~m}$ elevation). The location falls under IndoGangatic plains of Eastern Uttar Pradesh, India. This site is characterized by sub-humid and sub-tropical climate observing mean annual rainfall $1190 \mathrm{~mm}$, mainly received during July to September, however, the occasional showers during winter (October-mid February) and also in summer (April-mid June) also not un-common. Soil sample (0 to $30 \mathrm{~cm} \mathrm{depth)} \mathrm{was}$ taken with auger after the land had been prepared for transplanting and analyzed for physical and chemical properties using standard procedures: $\mathrm{pH}, \mathrm{EC}$, available phosphorus and potassium (Jackson, 1973), organic corbon (Walkley and Black, 1934); and available nitrogen (Subbaiah and Asija, 1956). The corresponding clay loam sodic soil had the $\mathrm{pH} 8.56, \mathrm{EC} 0.42 \mathrm{dSm}^{-1}$, organic carbon $0.35 \%$, available nitrogen $190.44 \mathrm{~kg} \mathrm{ha}^{-1}$ available phosphors $17.86 \mathrm{~kg} \mathrm{ha}^{-1}$ and available potassium $229.34 \mathrm{~kg} \mathrm{ha}^{-1}$

Experimental design and treatments: The experiment was conducted during two consecutive cropping seasons during year 2004-05 and 2005-06 and laid out in Spit Plot Design with four replications, wherein main plot was assigned with spacing treatments and sub-plot with soil fertility levels. The spacing treatments were $S_{1}-75 \times 60 \mathrm{~cm}, S_{2}-75 \times 75 \mathrm{~cm}$ and $S_{3}-90 \times 75$ $\mathrm{cm}$. Soil fertility treatments were constituted by manipulating the major plant nutrients (nitrogen, phosphorus and potassium) of soil through the application of NPK fertilizers at varying levels i.e. $\mathrm{F}_{1}$ - control (no NPK fertilizers), $F_{2}$ - 60:40:40 kg NPK ha ${ }^{-1}, F_{3}-$ 80:60:60 kg NPK ha ${ }^{-1}$ and $F_{4}-100: 80: 80$ NPK kg ha ${ }^{-1}$. Plant material and crop management: Cape gooseberry genotype S-101 (Suttind Seeds Pvt. Ltd, New Delhi) was used in this study. For two consecutive year's experiments, seeds of cape gooseberry were sown in semi-control polyhouse during mid of July 2004 and 2005. Twenty six days old seedlings of uniform vigor and size were transplanted as per the spacing treatments during second week of August. The size of individual plots was $9.0 \times 3.0 \mathrm{~m}$. The source for nitrogen, phosphorus and potassium fertilizers was urea ( $\mathrm{N} \mathrm{46 \% ),} \mathrm{single}$ super phosphate $\left(\begin{array}{lll}16 \% & \mathrm{P}_{2} \mathrm{O}_{5}\end{array}\right)$ and murate of potash $\left(60 \% \mathrm{~K}_{2} \mathrm{O}\right)$. One-third nitrogen and full amount of phosphorus and potassium were applied during last preparation of experimental soil. Remaining quantity of nitrogen was divided into two equal parts and top dressed at 45 and 75 days after transplanting. Other cultural operations including irrigation, weeding etc were similar for all the treatments.

Data collection and analysis: Five plants were randomly taken from two center lines in each plot for recording the data on plant height, number of branches per plant and number of leaves per plant and average value of each parameter was worked out. Plant height and number of branches were measured/ counted at the end of cropping cycle (last round of fruit harvest) while number of leaves produced on the plant was counted periodically and cumulated for total number of leaves per plant. Twenty fruits were taken for measuring fruit weight and volume. Fruit weight was recorded with the help of physical balance while volume of fruits determined by water displacement method. The husked fruits were dipped one by one in a half filled (with water) measuring cylinder; the increased volume of water due to fruit dipping was recorded, thus the average volume of fruit was calculated by dividing total number of fruits (20) and expressed in $\mathrm{cm}^{3}$. Fruit yield $\left(\mathrm{q} \mathrm{ha}^{-1}\right)$ was obtained on the basis of net plot yield. Total soluble solids in juice of ripe berries were determined with the help of Hand Refractometer (Erma, Japan) and data were expressed in ${ }^{0}$ Brix by calibrating at $20^{\circ} \mathrm{C}$. Titrable acidity in fruit juice sample was determined using N/10 NaOH solution. Ascorbic acid was estimated as per AOAC (1990). Reducing, non-reducing 
and total sugars in juice of ripe fruits were estimated using Fehling solution as described by Rangana (1986). Data collected during the course of investigation were analyzed as per standard procedure advocated by Panse and Sukhatme (1985) at 5\% level of level of significance.

\section{RESULTS AND DISCUSSION}

Effect of plant spacing: In the present study plant height increased progressively with the reduction of the plant spacing in both the years (Table 1). In other words, increased plant population per unit area exhibited taller plants. The tallest plants were observed at closest spacing $(75 \times 60 \mathrm{~cm})$ which was significant over widest spacing $(75 \times 90 \mathrm{~cm})$ but at par with medium spacing $(75 \times 75 \mathrm{~cm})$. At closer spacing, competition for space and light might be the reason for increased plant height. Contrary to the spacing effects on plant height, the number of branches per plant was increased with increase in plant spacing during both the years (Table 1). Significantly maximum number of branches was noted at widest spacing $(75 \times 90 \mathrm{~cm})$ compared with closet spacing $(75 \times 60 \mathrm{~cm})$. The medium spacing $(75 \times 75 \mathrm{~cm})$ was found at par with $90 \times 75 \mathrm{~cm}$ as well as $75 \times 60 \mathrm{~cm}$ spacing. Comparatively more ground space to the plants at wider spacing could provide the chance for better utilization resources. It also indicated a shift in the most favourable environment in root growth consists of optimal moisture availability. This lead to increase root activities, which might have been resulted in better nutrient uptake, subsequently better plant growth. The taller plant under closet spacing may probably reduce the side branching and have diverted the nutrient to the apical growth. Significant increase in plant height at closer spacing and more number of branches per plant at wider spacing in cape gooseberry was also reported by Girapu and Kumar (2006) under Sabour (Bihar, India) conditions. Total numbers of leaves per plant was also influenced due to different plant spacing's during both the years (Table 1). Maximum numbers of leaves per plant was recorded at widest spacing $(75 \times 90 \mathrm{~cm})$, which was significant over rest of two spacing treatments. Plants spaced at 75 x $60 \mathrm{~cm}$ produced minimum number of leaves per plant. Increased number of leaves per plant under wider spacing is attributed to the fact that plant had more number of branches, space for spread and also seems to have less competition for soil nutrients, solar

Table 1. Effect of plant spacing and soil fertility levels on vegetative growth of cape gooseberry.

\begin{tabular}{|c|c|c|c|c|c|c|}
\hline \multirow[t]{2}{*}{ Treatment } & \multicolumn{2}{|c|}{$\begin{array}{l}\text { Plant height } \\
\text { (cm) }\end{array}$} & \multicolumn{2}{|c|}{$\begin{array}{l}\text { Number of branches per } \\
\text { plant }\end{array}$} & \multicolumn{2}{|c|}{ Number of leaves per plant } \\
\hline & $1^{\text {st }}$ year & $2^{\text {nd }}$ year & $1^{\text {st }}$ year & $2^{\text {nd }}$ year & $1^{\text {st }}$ year & $2^{\text {nd }}$ year \\
\hline \multicolumn{7}{|l|}{ Plant spacing (S) } \\
\hline$S_{1}-75 \times 60 \mathrm{~cm}$ & 103.41 & 100.35 & 32.13 & 30.47 & 146.58 & 144.09 \\
\hline$S_{2}-75 \times 75 \mathrm{~cm}$ & 100.53 & 98.03 & 32.96 & 31.78 & 156.43 & 152.81 \\
\hline $\mathrm{S}_{3}-75 \times 90 \mathrm{~cm}$ & 96.68 & 93.16 & 34.14 & 32.49 & 167.31 & 162.70 \\
\hline $\mathrm{SEm} \pm$ & 2.20 & 2.15 & 0.55 & 0.75 & 2.55 & 3.15 \\
\hline $\mathrm{CD}_{(\mathrm{P}=0.05)}$ & 5.39 & 5.27 & 1.36 & 1.84 & 6.24 & 7.71 \\
\hline \multicolumn{7}{|l|}{ Soil fertility levels $(F)$} \\
\hline $\mathrm{F}_{0}$-control & 81.44 & 78.73 & 28.65 & 27.45 & 133.20 & 127.48 \\
\hline $\mathrm{F}_{1}-60: 40: 40 \mathrm{~kg} \mathrm{ha}^{-1}$ & 97.24 & 94.16 & 33.53 & 31.07 & 155.60 & 150.75 \\
\hline $\mathrm{F}_{2}-80: 60: 60 \mathrm{~kg} \mathrm{ha}^{-1}$ & 107.27 & 104.19 & 34.58 & 32.98 & 163.47 & 162.01 \\
\hline $\mathrm{F}_{3}-100: 80: 80 \mathrm{~kg} \mathrm{ha}^{-1}$ & 114.88 & 111.65 & 35.78 & 34.82 & 174.82 & 172.55 \\
\hline SEm \pm & 2.03 & 2.66 & 0.82 & 0.91 & 3.46 & 4.27 \\
\hline $\mathrm{CD}_{(\mathrm{P}=0.05)}$ & 5.88 & 5.54 & 1.68 & 1.87 & 7.11 & 8.75 \\
\hline
\end{tabular}

Table 2. Effect of plant spacing and soil fertility levels on physical characteristics of cape gooseberry fruits.

\begin{tabular}{|c|c|c|c|c|}
\hline \multirow[t]{2}{*}{ Treatment } & \multicolumn{2}{|c|}{ Average fruit weight (g) } & \multicolumn{2}{|c|}{ Average fruit volume $\left(\mathrm{cm}^{3}\right)$} \\
\hline & $1^{\text {st }}$ year & $2^{\text {ndit }}$ year & $1^{\text {st }}$ year & $2^{\ln }$ year \\
\hline \multicolumn{5}{|l|}{ Plant spacing (S) } \\
\hline $\mathrm{S}_{1}-75 \times 60 \mathrm{~cm}$ & 8.59 & 8.50 & 8.07 & 7.97 \\
\hline $\mathrm{S}_{2}-75 \times 75 \mathrm{~cm}$ & 8.93 & 8.84 & 8.31 & 8.21 \\
\hline $\mathrm{S}_{3}-75 \times 90 \mathrm{~cm}$ & 9.26 & 9.18 & 8.57 & 8.49 \\
\hline $\mathrm{SEm} \pm$ & 0.14 & 0.14 & 0.15 & 0.15 \\
\hline $\mathrm{CD}_{(\mathrm{P}=0.05)}$ & 0.35 & 0.35 & 0.37 & 0.36 \\
\hline \multicolumn{5}{|l|}{ Soil fertility levels $(F)$} \\
\hline $\mathrm{F}_{0}$-control & 7.83 & 7.73 & 7.52 & 7.43 \\
\hline $\mathrm{F}_{1}-60: 40: 40 \mathrm{~kg} \mathrm{ha}^{-1}$ & 8.89 & 8.82 & 8.38 & 8.25 \\
\hline $\mathrm{F}_{2}-80: 60: 60 \mathrm{~kg} \mathrm{ha}^{-1}$ & 9.37 & 9.23 & 8.60 & 8.50 \\
\hline $\mathrm{F}_{3}-100: 80: 80 \mathrm{~kg} \mathrm{ha}^{-1}$ & 9.62 & 9.57 & 8.77 & 8.71 \\
\hline SEm \pm & 0.19 & 0.19 & 0.21 & 0.21 \\
\hline $\mathrm{CD}_{(\mathrm{P}=0.05)}$ & 0.38 & 0.39 & 0.44 & 0.43 \\
\hline
\end{tabular}


energy. These findings are in agreement with the reports of Ghimire et al. (2002) in tomato investigated at Hisar, Haryana (India).

During the present study, plant spacing affected the fruit weight as well as fruit volume markedly, indicating the closest spaced plants having the smallest fruits, while the widest spaced plants had the largest fruits in both the years (Table 2). From the data it was noted that average fruit weight was maximum at widest spacing $(90 \times 75 \mathrm{~cm})$ which was significantly higher than the fruits harvested from the plants at closet spacing $(75 \mathrm{x}$ $60) \mathrm{cm}$ spacing. Average fruit weight under widest spacing $(90 \times 75 \mathrm{~cm})$ was statistically at par with average fruit weight harvested from the plants at medium spacing $(75 \times 75 \mathrm{~cm})$ spacing under study. Fruit volume was in similar trend as fruit weight. Minimum fruit weight as well as fruit volume was recorded in the fruits harvested from closest spacing $(75 \times 60 \mathrm{~cm})$. It might be due to fact that the nutrient and light supply deceased in closer spacing as compared with wider spacing which affected the photosynthesis and translocation of photosynthates ultimately resulting small size fruits. The decrease in size due to close spacing was in agreement with observations in tomato reported by Singh et al. (2002) worked at Agra, Uttar Pradesh (India). Fruit yield was significantly affected by plant spacing treatments (Fig. 1a). Results indicated that the fruit yield was increased with increase in plant density per unit area and resulted highest fruit yield with closest spacing $(75 \times 60 \mathrm{~cm})$; although it was at par with $75 \times 75 \mathrm{~cm}$ spacing. Plants spaced at $75 \times 60$ $\mathrm{cm}$ resulted $6.60 \%$ and $7.91 \%$ (in first and second year, respectively) higher yield as compared with $90 \mathrm{x}$ $75 \mathrm{~cm}$ spacing. This was probably due to increase in the number of plants per unit area, which might contribute to the extra yield per unit area leading to high yield. The progressive increase in the fruit yield (from 81.32 to $8669 \mathrm{q} \mathrm{ha}^{-1}$ in the first year and from 77.43 to $83.56 \mathrm{qha}^{-1}$ in the second year trial) as planting density increases was an indicative of the fact that at higher planting density individual plant performance is decreased but the higher number of plants per unit area compensate for lower individual performance, consequently yielding more fruits than the lower planting densities. In this study, widely spaced plants produced more vigorous vegetative growth as compared with the closely spaced plants, but per unit area yield were significantly higher under close planting. Klinac (a)

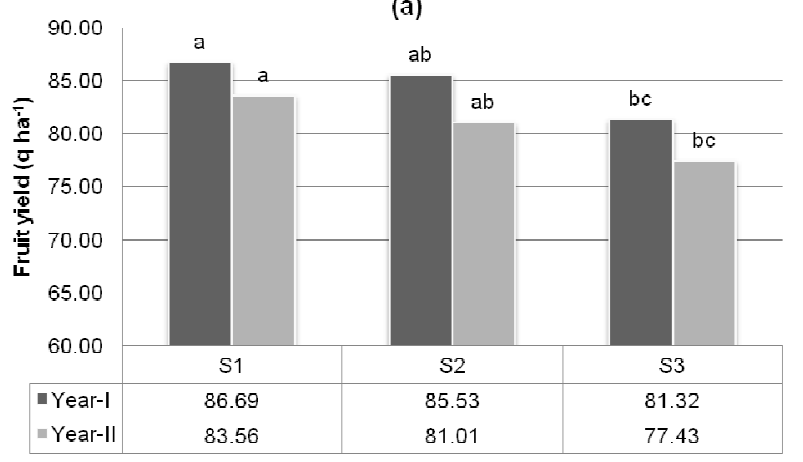

(b)

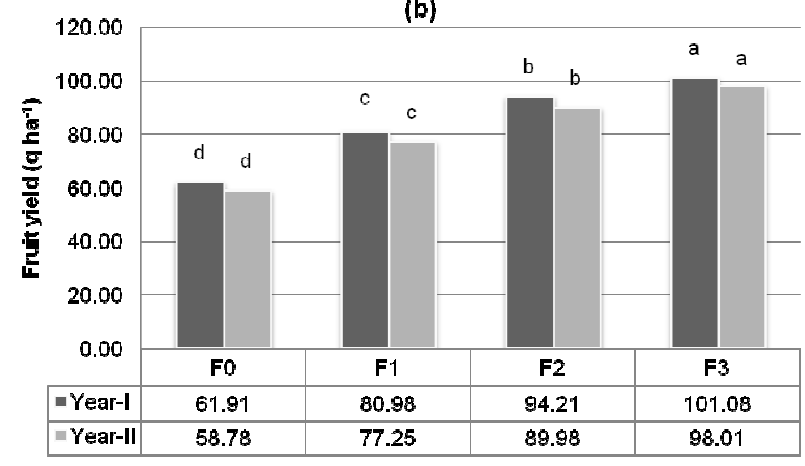

Fig.1. Effect of plant spacing (a) and soil fertility levels $(b)$ on fruit yield of cape gooseberry. Bar with different letters within same year in the same chart indicates significant difference $(P=0.05)$. Plant spacings: $S_{1}=60 \times 75 \mathrm{~cm}, S_{2}=75 \times 75 \mathrm{~cm}$ and $S_{3}$ $=90 \times 75 \mathrm{~cm}$; soil fertility levels $\left(\mathrm{kg} \mathrm{ha} \mathrm{C}^{-1}\right): F_{0}=$ control (no fertilizers), $F_{1}=60: 40: 40, F_{2}=80: 60: 60$ and $F_{3}=100: 80: 80$.

Table 3. Effect of plant spacing and soil fertility levels on total soluble solids, acidity and ascorbic acid content of cape gooseberry fruits.

\begin{tabular}{|c|c|c|c|c|c|c|}
\hline \multirow[t]{2}{*}{ Treatment } & \multicolumn{2}{|c|}{ Total soluble solids $\left({ }^{0}\right.$ Brix $)$} & \multicolumn{2}{|c|}{ Acidity (\%) } & \multicolumn{2}{|c|}{ Ascorbic acid (mg per $100 \mathrm{~g}$ ) } \\
\hline & $1^{\text {st }}$ year & $2^{\text {nd }}$ year & $1^{\text {st }}$ year & $2^{\text {nd }}$ year & $1^{\text {st }}$ year & $2^{\text {nd }}$ year \\
\hline Plant spacing (S) & & & & & & \\
\hline $\mathrm{S}_{1}-75 \times 60 \mathrm{~cm}$ & 14.40 & 14.35 & 1.28 & 1.28 & 45.32 & 43.85 \\
\hline$S_{2}-75 \times 75 \mathrm{~cm}$ & 14.57 & 14.54 & 1.29 & 1.31 & 46.19 & 44.95 \\
\hline $\mathrm{S}_{3}-75 \times 90 \mathrm{~cm}$ & 14.76 & 14.63 & 1.32 & 1.33 & 46.71 & 45.80 \\
\hline $\mathrm{SEm} \pm$ & 0.21 & 0.17 & 0.02 & 0.02 & 0.63 & 0.63 \\
\hline $\mathrm{CD}_{(\mathrm{P}=0.05)}$ & NS & NS & NS & NS & NS & NS \\
\hline Soil fertility level (F) & & & & & & \\
\hline $\mathrm{F}_{0}$-control & 13.67 & 13.46 & 1.22 & 1.23 & 40.88 & 40.54 \\
\hline $\mathrm{F}_{1}-60: 40: 40 \mathrm{~kg} \mathrm{ha}^{-1}$ & 14.59 & 14.56 & 1.30 & 1.31 & 46.35 & 44.63 \\
\hline $\mathrm{F}_{2}-80: 60: 60 \mathrm{~kg} \mathrm{ha}^{-1}$ & 14.87 & 14.88 & 1.32 & 1.33 & 48.11 & 46.46 \\
\hline $\mathrm{F}_{3}-100: 80: 80 \mathrm{~kg} \mathrm{ha}^{-1}$ & 15.18 & 15.12 & 1.34 & 1.36 & 48.94 & 47.83 \\
\hline $\mathrm{SEm} \pm$ & 0.24 & 0.24 & 0.02 & 0.02 & 0.88 & 0.86 \\
\hline $\mathrm{CD}_{(\mathrm{P}=0.05)}$ & 0.50 & 0.50 & 0.03 & 0.04 & 1.82 & 1.77 \\
\hline
\end{tabular}


Table 4. Effect of plant spacing and soil fertility levels on reducing, non-reducing and total sugars of cape gooseberry fruits.

\begin{tabular}{|c|c|c|c|c|c|c|}
\hline \multirow[t]{2}{*}{ Treatment } & \multicolumn{2}{|c|}{ Reducing Sugars (\%) } & \multicolumn{2}{|c|}{ Non-reducing sugars (\%) } & \multicolumn{2}{|c|}{ Total sugars (\%) } \\
\hline & $T^{\text {th }}$ year & $2^{\text {nd }}$ year & $T^{x}$ year & $2^{\text {nd }}$ year & $T^{\text {t year }}$ & $2^{\text {nth }}$ year \\
\hline Plant spacing (S) & & & & & & \\
\hline $\mathrm{S}_{1}-75 \times 60 \mathrm{~cm}$ & 4.64 & 4.53 & 3.80 & 3.68 & 8.44 & 8.21 \\
\hline$S_{2}-75 \times 75 \mathrm{~cm}$ & 4.76 & 4.61 & 3.89 & 3.75 & 8.65 & 8.36 \\
\hline $\mathrm{S}_{3}-75 \times 90 \mathrm{~cm}$ & 4.83 & 4.67 & 3.95 & 3.82 & 8.78 & 8.49 \\
\hline SEm \pm & 0.08 & 0.08 & 0.07 & 0.06 & 0.13 & 0.18 \\
\hline $\mathrm{CD}_{(\mathrm{P}=0.05)}$ & NS & NS & NS & NS & NS & NS \\
\hline Soil fertility level (F) & & & & & & \\
\hline $\mathrm{F}_{0}$-control & 4.43 & 4.29 & 3.57 & 3.46 & 8.00 & 7.75 \\
\hline $\mathrm{F}_{1}-60: 40: 40 \mathrm{~kg} \mathrm{ha}^{-1}$ & 4.65 & 4.52 & 3.80 & 3.71 & 8.45 & 8.23 \\
\hline $\mathrm{F}_{2}-80: 60: 60 \mathrm{~kg} \mathrm{ha}^{-1}$ & 4.89 & 4.75 & 4.03 & 3.86 & 8.94 & 8.61 \\
\hline $\mathrm{F}_{3}-100: 80: 80 \mathrm{~kg} \mathrm{ha}^{-1}$ & 4.98 & 4.85 & 4.12 & 3.97 & 9.10 & 8.82 \\
\hline SEm \pm & 0.12 & 0.10 & 0.11 & 0.07 & 0.18 & 0.21 \\
\hline $\mathrm{CD}_{(\mathrm{P}=0.05)}$ & 0.22 & 0.19 & 0.22 & 0.14 & 0.37 & 0.44 \\
\hline
\end{tabular}

(1986) also noted higher fruit yield of cape gooseberry with increased planting density in New Zeeland. Mehla et al. (2000) also observed higher fruit yield with increased plant population per unit area in tomato under Kaul conditions of Hisar (Haryana, India). Ahmad (2009) observed higher fruit yield of strawberry under close planting at Srinagar, Jammu \& Kashmir (India). Tuan and Mao (2015) studied on tomato at Thai Nguyen (Vietnam) reported that fruit number, fruit weight as well as fruit yield markedly increased in low planting density (25974 plants ha ${ }^{-1}$ ).

During the present study total soluble solids acidity, reducing, non-reducing, total sugars and ascorbic acid contents of fruits were slightly influenced by plant spacing but the effect was found non-significant (Table 3; Table 4). The highest amount of T.S.S., acidity, reducing, non-reducing and total sugar and ascorbic acid contents were recorded at 75 x $90 \mathrm{~cm}$ spacing followed by $75 \times 75 \mathrm{~cm}$ and lowest at $75 \times 60 \mathrm{~cm}$. These results are in accordance with the findings in tomato reported by Raghav (2000) studied at Nagina, Uttar Pradesh (India).

Effect of soil fertility: Soil fertility levels had significantly effects on plant height during both the years (Table 1). Each elevated levels of soil fertility resulted significant increase in plant height and thus recorded maximum with the application of 100:80:80 $\mathrm{kg} \mathrm{NPK} \mathrm{ha}{ }^{-1}$. The minimum plant height was measured in control. The probable reason for increased plant height with highest level of NPK application is might be attributed to more uptakes of applied nutrients by the plants; needed for protein and protoplasm synthesis for higher rate of meiosis, resulting better photosynthesis and plant growth and ultimately increased the plant height. Results of this study are in close conformity to the findings of Singh et al. (1977) reported in cape gooseberry studied at Basti, Uttar Pradesh (India). Number of branches as well number of leaves per plant was also increased with each increased levels of soil fertility (Table 1). Both the parameters were maximum with the application of 100:80:80 kg NPK ha followed by 80:60:60 $\mathrm{kg} \mathrm{NPK} \mathrm{ha}^{-1}, 60: 40: 40 \mathrm{~kg}$ NPK $\mathrm{ha}^{-1}$ and minimum in control. Prasad et al. (1985) also recorded significantly increased number of branches in cape gooseberry with the application of $100 \mathrm{~kg} \mathrm{~N} \mathrm{ha}^{-1}$ while the effect of phosphorus and potassium was nonsignificant. Similar results were also recorded in tomato by Mehla et al. (2000). The applied nutrients have key role in assimilation of amino acids, nucleic acids and regulation of many metabolic processes, which in turns increased photosynthetic efficiency (Tisdale, 1997). Increase in number of branches per plant due to increased soil fertility is attributed to more availability of applied nutrients, specially nitrogen, which tends to vigorous growth of plant remitting profuse branching and leaf production.

During both the years, soil fertility influenced the average fruit weight as well as fruit volume (Table 2) as considerably higher fruit weight and fruit volume noted with elevated soil fertility resulted compared with control. Both fruit weight and volume was highest with the application of 100:80:80 $\mathrm{kg}^{\mathrm{NPK}} \mathrm{ha}^{-1}$ which was

significantly superior over 60:40:40 kg NPK ha- ${ }^{-1}$ and control, but at par with 80:60:60 $\mathrm{kg} \mathrm{NPK} \mathrm{ha}^{-1}$. Fruit yield per unit area $\left(\mathrm{q} \mathrm{ha}^{-1}\right)$ increased progressively with elevated levels of soil fertility as compared with control (Fig. 1b). The results were in similar pattern during both the years. It is evident from data that fruit yield per unit area was significantly increased with each increased levels of NPK fertilizers and recorded highest with the application of 100:80:80 $\mathrm{kg} \mathrm{NPK} \mathrm{ha}^{-1}$. The high yield is attributed to increased availability of $\mathrm{N}, \mathrm{P}$ and $\mathrm{K}$ with elevated soil fertility levels as applied nutrients helps in vigorous growth of plant with increased number of branches, number of flowers and fruits. Chahal and Bal (2005) studied the effect of NPK nutrition on cape gooseberry under high soil $\mathrm{pH}$ (8.4) at Amritsar, Punjab (India) and emphasized that NPK nutrition is necessary for improving plant growth characters and maximizing the fruit yield. Results of our study are in close conformity to the finding of Singh et al. (1977) and Prasad et al. (1985) reported in cape gooseberry studied at Basti, Uttar Pradesh (India). 
In the present study marked influence on quality characters of fruits viz.; total soluble solids, acidity, ascorbic acid contents were found due to variation in NPK levels during both the years (Table 3). All these quality characters were increased with increasing levels of NPK fertilizers and recorded maximum with the application of 100:80:80 kg NPK/ha. The reducing, non-reducing and total sugars of fruit were also increased due to increased soil fertility levels (Table 4). The increase in total soluble solids and sugars in fruits due to NPK application might be due to fact that these nutrients are related to carbohydrates synthesis. When the nutrient supply became insufficient, the limited synthesized carbohydrates meet the requirements of only vegetative parts. Contrary to this, when adequate supply of nutrients is available, the synthesized carbohydrates translocated to the fruits, which ultimately increased the total soluble solids and sugars. Beneficial effect of applied nutrients (N, P and K) on biochemical parameters have been reported by Singh et al. (1977) and Prasad et al. (1985) in cape gooseberry studied at Basti, Uttar Pradesh and Sabour Bihar (India), respectively. Girapu and Kumar (2006) obtained maximum yield (134.44 $\left.\mathrm{q} \mathrm{ha}^{-1}\right)$ of cap gooseberry with the application of $90 \mathrm{~kg} \mathrm{~N} \mathrm{ha}{ }^{-1}$ under Sabour conditions of Bihar (India).

\section{Conclusion}

Production potential of cape gooseberry (Physalis peruviana L.) in sodic soil ( $\mathrm{pH}$ 8.56) of Eastern Uttar Pradesh (India) was studied under varying plant spacing $\left(S_{1}-75 \times 60 \mathrm{~cm}, S_{2}-75 \times 75 \mathrm{~cm}\right.$ and $S_{3}-90 \times 75$ $\mathrm{cm})$ and fertility levels $\left(\mathrm{F}_{0^{-}}\right.$no NPK fertilizers, $\mathrm{F}_{1^{-}}$ 60:40:40, $\mathrm{F}_{2}-80: 60: 60$, and $\mathrm{F}_{3}-100: 80: 80 \mathrm{~kg} \mathrm{NPK} \mathrm{ha}^{-1}$ ). Findings revealed that wide spacing $(90 \times 75 \mathrm{~cm})$ resulted taller plants with more number of branches and leaves per plant, but fruit yield was maximum under close spacing $(75 \times 60 \mathrm{~cm})$; although these results were statistically at par $\left(\mathrm{P}_{=0.05}\right)$ with medium spacing $(75 \times 75 \mathrm{~cm})$ in both the cases. Higher soil fertility levels increased plant growth, fruit yield as well as physio-chemical quality of fruits with maximum values under 100:80:80 $\mathrm{kg} \mathrm{NPK} \mathrm{ha}^{-1}$. It can be concluded that the plant spacing of $75 \times 75 \mathrm{~cm}$ and NPK @ 100:80:80 kg ha ${ }^{-1}$ is advisable for cape gooseberry cultivation in sodic soils ( $\mathrm{pH}$ 8.56) of Eastern Uttar Pradesh (India) for obtaining high yield of better quality fruits.

\section{REFERENCES}

Ahmad, M.F. (2009). Effect of planting density on growth and yield of strawberry. Indian J. Hort., 66 (1): 132134.

AOAC (1990). Official Methods for Analytical Chemists, $15^{\text {th }}$ ed. Washington DC, USA.

Ayala, C. (1992). Evaluation of three planting distances and three systems of pruning in cape gooseberry under greenhouse conditions. Acta Hort., 310: 206.

Chahal, T.S. and Bal, J.S. (2005). Effect of NPK on growth and yield of cape gooseberry (Physalis peruviana L.). Haryana J. Hort. Sci., 34(3-4): 246-249.

Chattopadhyay, T.K. (1996). Cape gooseberry. In: Chattopadhyay T.K. (ed.) A Textbook on Pomilogy.Vol-II. Kalyani Publishers, Calcutta, India, pp. 209-314.

Crawford, M. (2004). Physalis: Groundcherries. Yearbook: West Austr. Nut and Tree Crops Assoc., 27: 42-51.

CSIR (1969). The Wealth of India (Vol.-VIII). CSIR, New Delhi, India, pp. 38-40.

Fischer, G., Herrera, A. and Almanza, P.J. (2011). Cape gooseberry ( Physalis peruviana L.). In: Yahia, E.M. (ed.) Postharvest biology and technology of tropical and subtropical fruits. Woodhead Publishing Ltd., Cambridge, UK. pp. 374-392.

Ghimire, J., Singh. N., Dahia. M.S. and Malik, Y.S. (2002). Response of nitrogen and method of planting on seed yield and seed quality of tomato (Lycopersicon esculentum Mill.) cv. Hisar Lalit. Haryana J. Hort Sci., 31(34): 2278-2280.

Girapu, R.K. and Kumar, A. (2006). Influence of nitrogen and spacing on growth, yield and economics of cape gooseberry (Physalis peruviana L.) production. In: Proceedings of national symposium on production utilization and export of underutilized fruits with commercial potentialities, BCKV, Mohanpur, West Bengal (India), Nov. 22-24, 2006. pp. 145-149.

Jackson, M.L. (1973). Soil chemical analysis. Prentice Hall of India Pvt. Ltd., New Delhi, India.

Khan, K.F, and Gowder, R.B. (1955). The cape gooseberry-a remunerative intercrop for orchards in Nilgiris. South Indian Hort. 3 (4): 104-107.

Klinac, D.J. (1986). Cape gooseberry (Physalis peruviana L.) production systems. New Zealand J. Exp. Agric., 14 (4): 425-430.

Legge, A.P. (1974). Notes on the history, cultivation and uses of Physalis peruviana L. J. Royal Hort. Society, 99 (7): 310-314.

Majumdar, B.C. (1979). Cape gooseberry. The jam fruit of India. World Crops. 31: 19-23.

Majumdar, B.C. and Bose, T.K. (1979). Analysis of cape gooseberry fruits. Plant Sci., 11: 101

Mehla, C.P., Srivastava, V.K. and Singh, J. (2000). Response of tomato (Lycopersicon esculentum) varieties to $\mathrm{N}$ and $\mathrm{P}$ fertilization and spacing. Indian J. Agric. Res., 34 (3): 182-184.

Mengel, K., Kirby, E.A., Kosegarten, H. and Appel, T. (2001). Principles of plant nutrition. Kluwer Acadmic Publishers, Dordrecht, The Netherlands.

Miranda, D., Ulrichs, C., and Fischer, G. (2010). Imbibition and percentage of germination of cape gooseberry (Physalis peruviana L.) seeds under $\mathrm{NaCl}$ stress Agron. Colomb., 28 (1): 29-35.

Morton, F.J. (1987). Cape Gooseberry, In: Morton, F.J. (ed.) Fruits of warm climates. University of Miami, Miami, USA, pp. 430-434.

Munns, R. and Tester, M. (2008). Mechanisms of salinity tolerance. Ann. Rev Plant Biol., 59: 651-681.

Panse, V.G. and Sukhatme, P.V. (1985). Statistical methods for agricultural workers, $4^{\text {th }}$ edn. ICAR Publications, New Delhi, India.

Prasad, I.D., Sengupta, B.N., Singh, R.K. and Singh, S. (1985). Effect of NPK on yield, yield attributes and quality of cape gooseberry (Physalis peruviana). Haryana J. Hort. Sci., 14 (3-4): 151-155.

Raghav, M. (2000). Effect of nitrogen and spacing plant 
growth, dry matter accumulation and quality of hybrid tomato. Prog. Hort., 32(1): 90-94.

Rangana, S. (1986). Handbook of analysis and quality control of fruit and vegetable products, $2^{\text {nd }}$ edn. Tata McGrew Hill Publishing Co., New Delhi, India.

Schwabe, K.A., Iddo, K. and Knap, K.C. (2006). Drain water management for salinity mitigation in irrigated agriculture. Am. J. Agric. Ecol., 88: 133-140.

Sharma P.C. and Gupta, S.K. (2010). CSSRI at a glance. Central Soil Salinity Research Institute, Karnal (Haryana), India.

Singh, A.K., Parmar, A.S. and Pathak, R. (2002). Effect of spacing and nitrogen doses on yield and its attributes of determinate and indeterminate types of hybrid tomato (Lycopersicon esculentum). Prog. Hort., 34 (2): 215217.

Singh, U.R., Pandey, I.C. and Prasad, R.S. (1977). The effect of $\mathrm{N}, \mathrm{P}$ and $\mathrm{K}$ on growth, yield and quality of cape gooseberry. Punjab Hort. J., 17 (3-4): 148-151.

Subbaiah, B.V. and Asija, G.L. (1956). A rapid procedure for estimation of available nitrogen in soils. Curr. Sci., 5: 656-659.

Tisdale, S.L., Nelson, W.L., Beaton, J.D. and Havlin, J.L. (1997). Soil fertility and fertilizers, $5^{\text {th }}$ edn. Prentice Hall of India Pvt. Ltd., New Delhi.

Trinchero G.D., Sozzi G.O., Cerri, A.M., Vilella, F. and Fraschina A.A. (1999). Ripening-related changes in ethylene production, respiration rate and cell-wall enzyme activity in goldenberry (Physalis peruviana L.), a solanaceous species. Postharvest Biol. Tech., 16: 139-145.

Tuan, N.M. and Mao, T.M. (2015). Effect of plant density on growth and yield of tomato (Solanum lycopersicum L.) at Thai Nguyen, Vietnam. Intl. J. Plant Soil Sci., 7(6): 357-361.

Walkley, A. and Black, A.I. (1934). Soil and plant analysis. Hans Publications, Bombay, India. 